\title{
PERAN ORANG TUA TERHADAP PENDIDIKAN ANAK USIA DINI DALAM PANDANGAN ISLAM
}

(The Role of Parents on Early Children's Education in Islamic Views)

\author{
Oleh: Denny Erica*) Haryanto $^{*)}$ Mari Rahmawati ${ }^{*}$ Irwin Ananta Vidada*) \\ *) Dosen FTI Universitas Bina Sarana Informatika
}

\begin{abstract}
From an Islamic point of view, children are a mandate given by Allah to their parents, to provide good and healthy education, involving families is a place for children to learn, communicate, communicate, and behave towards the environment associated with it, and a children will always need a lot of attention and affection from both parents. The role of parents in the development of early childhood education from an Islamic point of view must be able to provide an explanation of all the children born in a state of nature, instill monotheism and aqeedah truly to children, teach children to help prayer, teach children to read the Koran, motivate children to always pray, teach children to always be grateful, motivate children to worship at the mosque, teach children to always be naked, teach children to always maintain the cleanliness of the body, and teach children to love each other God's creatures. By involving parents in providing education that contains Islamic religious values, it is expected that these early childhood children can support the process of adaptation to the outside environment, bearing in mind that these early childhood have strong character and faith in the process of development of growth and development for child.
\end{abstract}

\section{Keywords: Parents, Education, Early Childhood, Islam}

\section{PENDAHULUAN}

Pada dasarnya lingkungan pendidikan yang paling pertama dan utama bagi anak-anak adalah pendidikan yang berasal dari lingkungan keluarga. Secara psikologis figur dari seorang ayah dan ibu akan sangat mempengaruhi perilaku dan pola berfikir dari seorang anak.

Dari sudut pandang Islam, anak merupakan amanah yang telah diberikan oleh Allah SWT kepada orang tuanya, untuk memberikan pendidikan yang baik dan sehat, dikarenakan keluarga merupakan tempat seorang anak untuk belajar, berinteraksi, berkomunikasi, dan berperilaku terhadap lingkungan disekitarnya, dan seorang anak akan selalu membutuhkan banyak perhatian dan kasih sayang dari kedua orangtuanya.

Pada usia anak-anak, setiap saat seorang anak akan menggunakan salah satu inderanya sebagai bentuk dari stimulus bagi pembentukan hubungan persarafan (sinapsis) yang dilakukan secara berulangulang sehingga menjadi suatu rekaman pengalaman dalam menentukan cara anak dalam berpikir, merasakan, berperilaku, dan belajar di masa sekarang dan yang akan datang. Sinapsis yang tidak mendapatkan stimulus yang dibutuhkan akan menghilang dan terjadi proses penghapusan koneksi saraf yang berlebihan dan tak diperlukan (synaptic pruning). (Erica, 2016)

Pendidikan yang baik dan sehat bagi seorang anak dapat dengan cara melakukan hubungan kedekatan yang hangat antara anak-anak dengan orang-orang terdekatnya, yaitu ayah dan ibu.

Selain lingkungan keluarga, seorang anak juga membutuhkan pendidikan yang berasal dari lingkungan sekolah sebagai sarana dan prasarana kegiatan belajar mengajar baik itu secara koqnitif, afektif, dan spikomotorik 
Menurut Undang-Undang Republik Indonesia Nomor 20 Tahun 2003 Tentang Sistem Pendidikan Nasional Pasal 1 Ayat 1, dinyatakan bahwa Pendidikan Anak Usia Dini adalah suatu upaya pembinaan yang ditujukan kepada anak sejak lahir sampai dengan usia enam tahun yang dilakukan melalui pemberian rangsangan pendidikan untuk membantu pertumbuhan dan perkembangan jasmani dan rohani agar anak memiliki kesiapan dalam memasuki pendidikan lebih lanjut. (Undang-Undang Republik Indonesia Nomor 20 Tahun 2003 Tentang Sistem Pendidikan Nasional)

Pada saat anak-anak diajak untuk bermain bersama, bernyanyi, berbicara, bercerita, dan belajar di dalam lingkungannya tersebut, maka secara psikologis akan sangat berpengaruh terhadap perubahan besar bagi tumbuh kembang dan potensi anak di masa depan.

Setiap orang tua yang memiliki seorang anak pasti berkeinginan anak-anak mereka kelak dapat menjadi orang yang sukses baik itu dalam ahlak, pendidikan, karier, dan lain sebagainya. Namun terkadang harapan tidak sesuai dengan kenyataan, entah karena terhambatnya komunikasi atau minimnya pengetahuan orang tua tentang bagaimana Islam memberikan tuntunan dan prdoman tentang memperlakukan anak sesuai dengan proporsinya. (Yani, Khaeriyah, \& Ulfah, 2017)

Ada 4 (empat) prinsip yang harus diperhatikan oleh orang tua dalam mengasuh anak-anak mereka, (Shofi, 2007) yaitu:

1. Memelihara fitrah anak (al-muhafazoh)

Upaya yang dilakukan orang tua untuk mendidik anak-anaknya, harus didasarkan bahwa setiap anak dilahirkan dalam keadaan fitrah (suci).

Secara fitrah, manusia cenderung dan berusaha mencari serta menerima kebenaran walaupun hanya bersemayam di dalam hati kecilnya. (Muhaimin \& Mujib, 1993)

2. Mengembangkan potensi anak (attanmiyah)

Seorang anak memiliki potensi yang besar untuk dapat distimulasi dengan baik pada usia dini, yaitu pada usia 0 sampai 4 tahun. Selain itu seorang anak memiliki keingintahuan yang kuat pada usia dini, sehingga memungkinkan untuk memberikan ilmu pengetahuan yang baik dan benar kepada seorang anak diusia dini.

3. Ada arahan yang jelas (al-taujih)

Maksudnya mengarahkan anak pada kesempurnaan, mengajarinya dengan berbagai aturan yang benar, dan tidak menuruti segala permintaan anak yang kurang baik.

Potensi terpendam dalam diri manusia yang dibawa sejak lahir akan menjadi pendorong serta penentu bagi kepribadian serta alat untuk mengabdi kepada Allah sehingga bimbingan terhadap perkembangan fitrah harus menuju arah yang jelas. (Jalaludin, 2001)

4. Bertahap (at-tadaruj)

Mendidik anak dengan penuh kesabaran dan ketelatenan, tidak tergesa-gesa ingin melihat hasilnya, namun dengan bertahap hingga pada akhirnya anak akan mengerti dan paham.

Pendidikan sebaiknya dilakukan secara bertahap sesuai dengan tahap kemampuan dan usia perkembangan anak, karena seorang anak akan mudah menerima, memahami, menghafal dan mengamalkan bila pendidikan dilakukan bertahap. (Prayitno \& Irwan, 2003)

Ada 4 (empat) macam pola asuh orang tua (parenting), yaitu:

1. Pola Asuh Demokratis

Adalah pola asuh yang memprioritaskan kepentingan anak, akan tetapi tidak raguragu mengendalikan mereka. Orang tua dengan pola asuh ini bersikap rasional, 
selalu mndasari tindakannya pada rasio atau pemikiran-pemikiran. Orang tua dengan pola asuh demokratis selalu bersikap realistis terhadap kemampuan anak, tidak berharap yang berlebihan bahkan sampai melampaui kemampuan anak. Orang tua dengan pola asuh ini juga memberikan kebebasan kepada anak untuk dapat memilih dan melakukan suatu tindakan dengan suatu pendekatan yang bersifat hangat kepada anak.

\section{Pola Asuh Otoriter}

Adalah pola asuh yang cenderung menetapkan standar mutlak yang harus dituruti dan dipetuhi oleh seorang anak, biasanya ada beberapa ancaman-ancaman dari orang tua terhadap anak. Sebagai contohnya, jika seoramg anak tidak mau makan maka tidak akan diajak bicara. Orang tua dengan pola asuh ini cenderung memaksa, memerintah, dan menghukum. Apabila seorang anak tidak mau melakukan apa yang dikatakan oleh orang tua, maka sebagai orang tua tidak akan segan-segan untuk memberikan hukuman kepada anak. Orang tua dengan pola asuh ini juga tidak mengenal kompromi, bahkan dalam komunikasi biasanya bersifat satu arah dan tidak memerlukan umpan balik dari anaknya untuk dapat mengerti terhadap anaknya tersebut.

3. Pola Asuh Permisif atau Pemanja Adalah suatu bentuk pola asuh yang biasanya memberikan pengawasan yang sangat longgar. Pada pola asuh ini juga memberikan kesempatan pada anaknya untuk melakukan sesuatu tanpa adanya pengawasan yang cukup dan cenderung tidak menegur atau memperingatkan anak, apabila anaknya sedang dalam bahaya, selain itu sangat sedikit bimbingan orang tua terhadap anak. Namun orang tua dengan pola asuh ini biasanya bersifat hangat sehingga seringkali disukai oleh anak.

\section{Pola Asuh Penelantar}

Adalah suatu bentuk pola asuh yang pada umumnya memberikan waktu dan biaya yang sangat minim dari orang tua kepada anaknya. Termasuk dalam pola asuh ini adalah perilaku penelantar secara fisik dan psikis dari ibu yang depresi, dan pada umumnya seorang ibu yang depresi tidak mampu memberikan perhatian baik secara fisik maupun psikis pada anakanaknya. (Baumrind, 1971)

\section{METODE PENELITIAN}

Metode pengumpulan data yang digunakan dalam penelitian ini menggunakan metode studi literatur yang terkait dengan peran orang tua dalam pendidikan anak dalam pandangan islam, yang dapat dijadikan sebagai dasar penelitian yang berkelanjutan.

\section{PEMBAHASAN}

Pada saat ini seringkali kita temukan perilaku anak yang menyalahi nilai-nilai kesopanan, etika, dan norma agama. Salah satu penyebabnya adalah kurangnya dan lemahnya pengawasan dan keseriusan dari pola asuh dan peranan orang tua dalam memberikan pendidikan kepada anak usia dini, sehingga menyebabkan seorang anak terkadang tumbuh kembang di lingkungan luar keluarga tanpa adanya pengawasn dan benteng keimanan yang cukup, dan hal ini dapat menimbulkan kebingungan bagi seorang anak di dalam mencari jati diri.

Apabila ditelusuri periode kehidupan yang ditempuh manusia mengalami pertumbuhan dan perkembangan beberapa fase, seperti masa pranatal, balita, kanakkanak remaja, dewasa dan tua. Masa yang sangat menentukan adalah sejak anak lahir sampai dengan usia 6 tahun, karena pada usia ini secara fisik maupun psikhologis anak belum berdaya, mereka hanya menerima apa yang diberikan oleh orang dewasa, pikiran dan hatinya masih suci, 
bagaikan kertas putih yang belum ternoda dan tergores sesuatu. Maka apa yang didengar dan dilihatnya akan diserap si anak dan langsung tersimpan dalam memorinya. (Basri, 2009)

Islam sangat mementingkan pendidikan anak usia dini, bahkan sebelum kelahiran si anak (dalam kandungan) si ibu telah dianjurkan untuk melakukan hal-hal yang baik dan menyenangkan, dengan harapan agar si anak kelak akan menjadi sehat, tangkas, cerdas dan tangguh. Seperti firman Allah SWT, "dan hendaklah takut kepada Allah orang-orang yang seandainya meninggalkan di belakang mereka anakanak yang lemah, yang mereka khawatir terhadap kesejahteraan mereka" (Q.S. AnNisa : 9), dan "Jagalah dirimu dan keluargamu dari api neraka." (Q.S. AtTahrim : 6)

Ada 10 (Sepuluh) peranan orang tua terhadap pendidikan anak usia dini menurut pandangan Islam, (Erica, 2016) yaitu:

\section{Anak Terlahir Dalam Keadaan Suci dan Bersih (Fitrah)}

Menurut pandangan Islam, setiap anak yang dilahirkan ke dunia ini dalam keadaan suci dan bersih (fitrah). Dari Abu Hurairah radhiyallahu'anhu berkata, Rasulullah shallallahu'alaihi wa sallam telah bersabda: "Tidaklah setiap anak yang lahir kecuali dilahirkan dalam keadaan fitrah. Maka kedua orang tuanyalah yang akan menjadikannya sebagai Yahudi, Nasrani, atau Majusi. Seperti hewan melahirkan anaknya yang sempurna, apakah kaliah melihat darinya buntung (pada telinga)?". Hadits ini diriwayatkan oleh AlImam Malik rahimahullahu dalam AlMuwaththa (No. 507); Al-Imam Ahmad rahimahullahu dalam Musnad-nya (No. 8739); Al-Imam Al-Bukhari rahimahullahu dalam Kitabul Jana'iz (N0. 1358,1359,1385), Kitabut Tafsir (No. 4775), Kitabul Qadar (No. 6599); Al-Imam Muslim rahimahullahu dalam Kitabul Qadar (No. 2658).

"Sesungguhnya seorang diantara kamu dikumpulkannya pembentukannya (kejadiannya) dalam rahim ibunya (embrio) selama empat puluh hari. Kemudian selama itu pula (empat puluh hari) dijadikan sepotong daging. Kemudian diutuslah beberapa malaikat untuk meniupkan ruh kepadanya (untuk menuliskan/menetapkan) empat kalimat (macam): rezekinya, ajal (umurnya), amalnya, dan buruk baik (nasibnya)." (HR. Bukhari Muslim)

Dari penjabaran beberapa hadits di atas, dapat dimaknai bahwasannya Allah telah memberikan amanah kepada orang tua untuk selalu menjaga, merawat, dan memberikan pendidikan yang baik untuk anak-anak mereka.

Letak peranan orang tua ini sudah terlihat ketika anak masih dalam kandungan yang selalu dijaga dengan baik oleh orang tuanya. Terkadang seorang ibu selalu membacakan dan mendengarkan bacaan ayat-ayat Al Qur'an sebagai bentuk pembelajaran bagi si calon bayi yang masih dalam kandungan, melakukan hal-hal yang baik dengan harapan kelak anak mereka kelak menjadi anak yang sholeh dan sholehah.

Peranan sang ayah yang selalu mencari nafkah dari uang yang halal juga merupakan bentuk stimulus dalam membentuk kharakter kepribadian pola pikir anak, dikarenakan seseorang yang memberi anaknya makan dengan makanan haram tidak akan mendapatkan kebaikan, sebaliknya makanan haram tersebut dapat merusak akhlak dan kebaikan yang ada pada diri anak. Inilah kenapa orangtua yang memberikan makanan haram pada anaknya seringkali memiliki anak yang susah diatur dan cenderung membangkang. Seperti firman Allah SWT, "Hai sekalian manusia, makanlah yang halal lagi baik dari apa yang terdapat di bumi, dan janganlah kamu 
mengikuti langkah-langkah syaitan; karena sesungguhnya syaitan itu adalah musuh yang nyata bagimu." (QS Albaqarah 168)

\section{Menanamkan Nilai-Nilai Tauhid dan Aqidah yang benar kepada anak}

Tauhid memiliki pengaruh dalam segala aspek kehidupan bagi seorang muslim, dan seseorang dapat dikatakan muslim manakala ia sudah beriman, karena iman merupakan kunci utama yang membentuk ke islaman seseorang. Iman dan Islam merupakan satu kesatuan yang saling mengisi. Iman tiada artinya tanpa amal shaleh, dan amal shaleh akan sia-sia tanpa dilandasi dengan iman kepada Allah (QS. Al-Ashr : 1-3)

Aqidah berisikan keyakinan terhadap adanya Tuhan dan ajaran yang benarnya datang dari Tuhan, meyakini dalam hati secara kokoh, tiada keraguan dan dipilih menjadi jalan hidup (Ensiklopedi Islam, 1994)

Rasulullah shallallahu'alaihi wasallam telah memberikan contoh aqidah yang kokoh ketika beliau mengajari anak dari paman beliau, yaitu Abdullah bin Abbas radhiyallahu'anhuma dalam sebuah hadits yang diriwayatkan oleh Al-Imam AtTirmidzi dengan sanad yang hasan, dimana Ibnu Abbas bercerita, "Pada suatu hari aku pernah berboncengan di belakang Nabi (di atas kendaraan), beliau berkata kepadaku: Wahai anak, aku akan mengajari engkau beberapa kalimat: Jagalah Allah, biscaya Allah akan menjagamu, Jagalah Allah, niscaya engkau akan dapati Allah di hadapanmu. Jika engkau memohon, memohonlah kepada Allah. Jika engkau meminta tolong, minta tolonglah kepada Allah. Ketahuilah, kalaupun seluruh umat (Jin dan Manusia) berkumpul untuk memberikan satu pemberian yang bermanfaat kepadamu, tidak akan bermanfaat hal itu bagimu, kecuali jika itu telah ditetapkan Allah (akan bermanfaat bagimu). Ketauilah, kalaupun seluruh umat
(Jin dan Manusia) berkumpul untuk mencelakakan kamu, tidak akan mampu mencelakakanmu sedikitpun, kecuali jika itu telah ditetapkan Allah (akan sampai dan mencelakakanmu). Pena telah diangkat, dan telah kering lembaran-lembaran".

"Dan (ingatlah) ketika Lukman berkata kepada anaknya, diwaktu ia memberi pelajaran kepadanya: Hai anakku, janganlah kamu mempersekutukan (Allah) sesungguhnya mempersekutukan (Allah) adalah benar-benar kelaliman yang besar" (QS. Lukman : 13)

Aqidah yang perlu ditanamkan kepada anak usia dini adalah tentang "dimana Allah berada?". Hal ini sangatlah penting, karena terkadang para orang tua dari kaum muslimin masih kurang benar dalam menyampaikan keberadaan Allah kepada anak mereka di usia dini, dengan mengatakan Allah ada dimana-mana, sebagian lagi mengatakan bahwa Allah di dalam pikiran dan hati kita, dan beragam pendapat lainnya yang tidak sesuai dengan Al-Quran dan hadits. Padahal sudah sangat jelas di dalam Al-Quran, "(yaitu) Yang Maha Pengasih, yang bersemayam di atas 'Arsy" (QS. Thaha : 5), di dalam surat ini tersirat ajaran aqidah yang dapat kita sampaikan kepada seorang anak usia dini pada saat mereka menanyakan berada dimanakah Allah?, maka kita bisa menjawabnya Allah bersemayam di atas 'Arsy. Sedangkan kata 'Arsy adalah bentuk mashdar dari kata kerja 'arasya - ya'risyu 'arsyan yang berarti bangunan, singgasana, istana atau tahta, dan meskipun kata 'Arsy mempunyai beberapa makna, tetapi pada umumnya yang dimaksudkan adalah suatu singgasana atau tahta Allah di atas langit ke tujuh.

Dalam hadits Mu'awiyyah bin Hakam As-Sulaimi radhiyallahu 'anhu mengatakan bahwasannya pada waktu itu, Rasulullah shalallahu 'alaihi wa sallam sedang mengajari seorang budak anak 
perempuan yang berkenaan dengan tauhid. Rasulullah shalallahu 'alaihi wa sallam bertanya kepada anak perempuan tersebut, "dimana Allah?" anak perempuan itu menjawab, "Allah di atas langit", kemudian beliau bertanya lagi, "Siapa saya?" jawab anak perempuan itu, "Engkau Rasulullah (utusan Allah)". Kemudian Rasulullah memerintahkan agar budak anak perempuan tersebut untuk dibebaskan dari status budaknya, dan berkata "dia seorang mukminah," (HR Abu Dawud : Nomor 930, dishahihkan Asy Syaikh Muhammad Nashiruddin Al-Albani Rahimahullah).

Penanaman aqidah juga dilakukan oleh Rasulullah shallallahu'alaihi wasallam kepada anak paman beliau, Abdullah bin Abbas radhiyallahu 'anhuma dalam sebuah hadits yang diriwayatkan oleh Al-Imam AtTirmidzi dengan sanad yang hasan. Ibnu Abbas bercerita,"Pada suatu hari aku pernah berboncengan di belakang Nabi (di atas kendaraan), beliau berkata kepadaku: wahai anak, aku akan mengajari engkau beberapa kalimat, jagalah Allah nisvaya Allah akan menjagamu, Jagalah Allah niscaya engkau akan dapati Allah di hadapanmu. Jika enkau memohon, mohonlah kepada Allah. Jika engkau meminta tolong, minta tolonglah kepada Allah. Ketahuilah, kalaupun seluruh umat (jin dan manusia) berkumpul untuk memberikan satu pemberian yang bermanfaat kepadamu, tidak akan bermanfaat hal itu bagimu, kecuali jika itu telah ditetapkan Allah (akan bermanfaat bagimu). Ketahuilah, kalaupun seluruh umat (jin dan manusia) berkumpul untuk mencelakakan kamu, tidak akan mampu mencelakakanmu sedikitpun, kecuali jika itu telah ditetapkan Allah (akan sampai dan mencelakakanmu). Pena telah diangkat, dan telah kering lembaran-lembaran”. Hadits ini mengandung suatu ajaran yang baik yang bisa disampaikan oleh orang tua kepada anak usia dini sebagai bentuk penanaman aqidah, agar kelak anak tersebut akan tumbuh kembang menjadi sosok manusia yang selalu bertawakal kepada Allah.

Dan aqidah yang paling penting yang harus disampaikan oleh orang tua kepada anak usia dini, adalah jangan pernah mempersekutukan Allah dengan apapun, karena sesungguhnya Allah berfirman, "Dan (ingatlah) ketika Lukman berkata kepada anaknya, diwaktu ia memberi pelajaran kepedanya: Wahai anakku, janganlah kamu mempersekutukan (Allah) sesungguhnya mempersekutukan (Allah) adalah benarbenar kezaliman yang besar," (QS. Luqman : 13).

\section{Mengajari Anak Untuk Shalat}

Pada dasarnya kewajiban bagi anak untuk mengerjakan shalat jika usianya sudah mencapai usia tujuh tahun, namun orang tua harus sudah mengajarkannya kepada anak mengenai tata cara shalat dan manfaat shalat itu pada saat usia anak masih di bawah tujuh tahun.

"Perintahkanlah anak-anak kalian untuk shalat saat berumur tujuh tahun dan pukulah mereka jika tidak shalat saat berumur sepuluh tahun, dan pisahkanlah mereka dalam tempat tidur." (HR Abu Dawud : 167)

Memperkenalkan dan mengajari shalat kepada anak usia dini memang merupakan suatu hal yang tidak mudah bagi orang tua, namun hal tersebut harus dilakukan dengan penuh kesabaran, seperti firman Allah:

"Dan perintahkanlah kepada keluargamu mendirikan shalat dan bersabarlah kamu dalam mengerjakannya. Kami tidak meminta rezqi kepadamu, Kamilah yang memberi rezqi kepadamu. Dan akibat (yang baik) adalah bagi orang yang bertaqwa" (QS. Thaha : 132)"

Untuk memperkenalkan shalat kepada anak usia dini, sebagai orang tua bisa saja dengan cara membiasakan diri untuk selalu mengajak anak untuk shalat secara berjamaah baik di rumah maupun di 
mushola dan masjid, dimana hal tersebut dapat membuat anak akan mulai terbiasa untuk melakukan shalat, dan hal ini bisa dikatakan sebagai suatu pendidikan parenting dengan metode education figurre, dimana orang tualah yang akan menjadi figurnya.

\section{Mengajari Anak Untuk Membaca Al- Quran}

Terkadang sebagai orang tua kita selalu fokus untuk mengajarkan anak untuk membaca dan menulis bahasa dengan huruf latin tapi lupa untuk mengenalkan dan mengajarkan anak untuk belajar membaca dan menulis bahasa dengan huruf arab, seperti apa yang telah diamanahkan oleh Rasulullah, dimana beliau bersabda kepada Malik bin Al-Huwairits dan kaumnya, "Pulanglah kepada keluargamu, tinggallah bersama mereka dan ajarkanlah (petunjuk Allah/Al-Quran) kepada mereka." (HR. AlBukhari No: 602). Selain itu Rasulullah juga bersabda, "Orang yang paling baik (di sisi Allah) di antara kamu adalah orang yang mempelajari dan mengajarkan Al-Quran." (HR. Al-Bukhari No: 4739).

\section{Memotivasi Anak Untuk Senantiasa Berdoa}

Sebagai orang tua kita harus dapat memberikan suatu ketenangan jiwa, kesejukan hati, dan ketentraman hidup kepada anak dengan selalu memberikan contoh kepada anak dengan membiasakan diri untuk selalu berdoa kepada Allah sebagai Tuhan Yang Maha Esa yang menciptakan seluruh alam semesta, bumi dan beserta isinya. Sebagaimana firman Allah, "(Yaitu) orang-orang yang beriman dan hati mereka menjadi tenteram dengan mengingat Allah. Ingatlah, hanya dengan mengingati Allah-lah hati menjadi tenteram." (QS. Ar-Ra'd : 28)

6. Mengajarkan Anak Untuk Bersyukur

Sebagaimana firman Allah, "Dan sesungguhnya telah Kami berikan hikmah kepada Lukman, yaitu: "Bersyukurlah kepada Allah. Dan barang siapa yang bersyukur (kepada Allah), maka sesungguhnya ia bersyukur untuk dirinya sendiri; dan barang siapa yang tidak bersyukur, maka sesungguhnya Allah Maha Kaya lagi Maha Terpuji." (QS. Lukman No. 12).

Salah satu doa yang dapat diajarkan oleh orang tua kepada anak, yaitu: "Ya Tuhanku, berilah aku ilham untuk tetap mensyukuri nikmat-Mu yang telah Engkau anugerahkan kepadaku dan kepada kedua orang ibu-bapakku dan untuk mengerjakan amal shalih yang Engkau ridhai, serta masukkanlah aku dengan rahmat-Mu ke dalam golongan hamba-hamba-Mu yang shalih." (QS. Al-Naml : 19)

\section{Memotivasi Anak Untuk Ke Masjid}

Sebagai orang tua hendaklah dapat mengenalkan dan mengajak anak-anak mereka untuk selalu beribadah di dalam masjid, dan berikanlah penjelasan dari beberapa manfaat dan keutamaan jika mereka selalu beribadah di dalam masjidmasjid Allah bersama dengan umat muslim lainnya kepada anak, sebagaimana firman Allah, "Hanyalah yang memakmurkan masjid-masjid Allah-lah orang-orang yang beriman kepada Allah dan hari kemudian, serta tetap mendirikan shalat, menunaikan zakat dan tidak takut (kepada siapapun) selain kepada Allah, maka merekalah orangorang yang diharapkan termasuk golongan orang-orang yang mendapat petunjuk." (QS At-Taubah : 18)

\section{Mengajari Anak Untuk Senantiasa Menjaga Aurat}

Sesungguhnya Allah telah berfirman, "Katakanlah kepada orang laki-laki yang beriman: "Hendaklah mereka menahan pandangannya, dan memelihara kemaluannya; yang demikian itu adalah lebih suci bagi mereka, sesungguhnya Allah Maha Mengetahui apa yang mereka perbuat". Katakanlah kepada wanita yang beriman: "Hendaklah mereka menahan 
pandangannya, dan kemaluannya, dan janganlah mereka menampakkan perhiasannya, kecuali yang (biasa) nampak dari padanya. Dan hendaklah mereka menutupkan kain kudung ke dadanya, dan janganlah menampakkan perhiasannya kecuali kepada suami mereka, atau ayah mereka, atau saudara-saudara laki-laki mereka, atau putera-putera saudara lelaki mereka, atau putera-putera saudara perempuan mereka, atau wanita-wanita islam, atau budak-budak yang mereka miliki, atau pelayan-pelayan laki-laki yang tidak mempunyai keinginan (terhadap wanita) atau anak-anak yang belum mengerti tentang aurat wanita. Dan janganlah mereka memukulkan kakinya agar diketahui perhiasan mereka sembunyikan. Dan bertaubatlah kamu sekalian kepada Allah, hai orang-orang yang beriman supaya kamu beruntung." (QS. An Nur : 30-31)

Pola mengajarkan anak untuk selalu dapat menutup aurat mereka, bisa dengan cara memberikan contoh perbuatan atau tindakan dari kedua orang tuanya, sebagai contoh: seorang ibu yang selalu memakai jilbab biasanya akan ditiru oleh anak-anak perempuan mereka, karena pada dasarnya para anak-anak itu senang meniru apa saja yang mereka lihat dan rasakan disekeliling mereka, namun demikian harus disesuaikan jilbab untuk anak-anak usia dini yang senang dengan corak yang beraneka warna, yang tentunya akan sangat berbeda dengan corak warna yang dipakai ibunya sebagai wanita dewasa.

\section{Mengajari Anak Untuk Senantiasa Menajaga Kebersihan Tubuh}

Memberikan penjelasan kepada anak bahwa di dalam menjaga kebersihan tubuh merupakan sesuatu hal yang di sukai oleh Allah SWT, bahkan Rasulullah Shallallahu 'alaihi wasallam telah bersabda, "Mandi pada hari Jum'at wajib bagi setiap orang yang telah baligh." (HR. Al-Bukhari No. $857 \& 895$ dan Muslim No. 1954)
Rasulullah Shallallahu 'alaihi wasallam juga telah bersabda, "Lima hal termasuk perkara fitrah: khitan, mencukur rambut kemaluan, menggunting kuku, mencabut rambut ketiak, dan memotong kumis." (HR. al-Bukhari no. 5889 dan Muslim no. 596)

Abu Hudzaifah mengatakan, "Adalah Rasulullah ketika bangun dari tidur malam beliau menggosok mulut dengan siwak." (HR. Al-Bukhari No. 245 dan Muslim No. 592)

\section{Mengajari Anak Untuk Saling Menyayangi Sesama Mahluk Ciptaan Allah}

Memberikan pelajaran kepada anak untuk selalu saling menyayangi sesama mahluk hidup, merupakan salah satu pendidikan dasar dalam hal membangun rasa saling menghargai, menghormati, dan selalu berbuat baik terhadap sesama mahluk ciptaan Allah.

Sebagai contohnya, seorang anak mulai diajarkan untuk selalu menghargai binatang dengan cara mengajaknya untuk memberikan makanan kepada binatang tersebut sebagai salah satu bentuk kasih sayang terhadap sesama mahluk hidup ciptaan Allah.

Contoh yang lain, sebagai orang tua sudah seharusnya selalu mengajak anaknya untuk dapat menghargai dan menghormati sesama manusia dengan cara bertingkahlaku yang sopan dan tidak berusaha untuk saling menyakiti, dan ini juga merupakan salah satu bentuk kasih sayang terhadap sesama mahluk hidup ciptaan Allah.

"Rasulullah shallallahu 'alaihi wasallam mencium Al-Hasan bin 'Ali, dan di sisi Nabi ada Al-Aqro bin Haabis AtTamimiy yang sedang duduk. Maka AlAqro berkata, "Aku punya 10 orang anak, tidak seorangpun dari mereka yang pernah kucium". Maka Rasulullah shallallahu 'alaihi wa sallam melihat kepada Al-Aqro lalu beliau berkata, "Barangsiapa yang tidak 
merahmati/menyayangi maka ia tidak akan dirahmati." (HR Al-Bukhari No 5997 dan Muslim No 2318)

$$
\text { Rasulullah Shallallahu 'alaihi }
$$

wasallam telah bersabda, "Para pengasih dan penyayang dikasihi dan di sayang oleh Ar-Rahmaan (Allah yang maha pengasih lagi maha penyayang), rahmatilah yang ada di bumi niscaya kalian akan dirahmati oleh Dzat yang ada di langit." (HR Abu Dawud no 4941 dan At-Thirmidzi no 1924 dan dishahihkan oleh Syaikh Albani dalam AsShahihah no 925)

\section{KESIMPULAN}

Peranan Orang Tua terhadap perkembangan pendidikan anak usia dini menurut sudut pandang islam haruslah dapat memberikan penjelasan bahwa sebenarnya semua anak itu terlahir dalam keadaan fitrah, menanamkan tauhid dan aqidah yang benar kepada anak, mengajari anak untuk mengerjakan shalat, mengajari anak untuk membaca Al Quran, memotivasi anak untuk selalu berdoa, mengajarkan anak untuk selalu bersyukur, memotivasi anak untuk beribadah di masjid, mengajari anak untuk selalu menjaga aurat, mengajari anak untuk selalu menjaga kebersihan tubuh, dan mengajari anak untuk saling menyayangi sesama mahluk ciptaan Allah.

Dengan peranan orang tua di dalam memberikan pendidikan yang mengandung nilai-nilai agama Islam, diharapkan anakanak usia dini tersebut dapat menjalani proses beradaptasinya dengan lingkungan luar, dikarenakan anak usia dini tersebut sudah memiliki kharakter dan keimanan yang kuat di dalam menjalani proses tumbuh kembang seorang bagi anak.

\section{REFERENSI}

Basri, R. (2009). Pendidikan Anak Usia Dini dalam Perspektif Islam. Retrieved from https://bdkpadang.kemenag.go.id/index .php?option $=$ com_content $\&$ view $=$ articl e\&id=442:pendidikan-anak-usia-dinidalam-perspektif-islam\&catid=41:topheadlines\&Itemid $=158$

Baumrind. (1971). Current Pattens of Parental Authority; Developmental Psychology Monographs. America: American Psychological Association.

Ensiklopedi Islam. (1994). In Islam (Cetakan 2). PT. Ichtiar Baru Van Hoeve.

Erica, D. (2016). Penerapan Parenting Pada Perkembangan Anak Usia Dini Menurut Sudut Pandang Islam. Cakrawala, XVII(2), 34-45. Retrieved from https://ejournal.bsi.ac.id/ejurnal/index.p $\mathrm{hp} /$ cakrawala/article/view/1286

Jalaludin. (2001). Teologi Pendidikan Jakarta. Jakarta: Raja Grafindo Persada.

Muhaimin, \& Mujib. (1993). Pemikiran Pendidikan Islam. Bandung: Trigenda Karya.

Prayitno, \& Irwan. (2003). Membangun Potensi Anak (Tugas dan Perkembangan Pendidikan Anak dan Anak Sholeh). Jakarta: Pustaka Tartibuana.

Shofi, U. (2007). Agar Cahaya Mata Makin Bersinar (Kiat-Kiat Mendidik Ala Rasulullah. Surakarta: Afra Publishing.

Undang-Undang Republik Indonesia Nomor 20 Tahun 2003 Tentang Sistem Pendidikan Nasional. (n.d.).

Yani, A., Khaeriyah, E., \& Ulfah, M. (2017). Implementasi Islamic Parenting Dalam membentuk Karakter Anak Usia Dini Di RA At-Taqwa Kota Cirebon. AWLADY: Jurnal Pendidikan Anak, 3(1), 153-174. 